\title{
Insects associated with syconia of Ficus citrifolia (Moraceae) in central Brazil
}

\author{
Priscila Canesqui da $\operatorname{Costa}^{1} \&$ Gustavo Graciolli²
}

\begin{abstract}
${ }^{1}$ Programa de Pós-graduação em Biodiversidade Animal, Departamento de Biologia, Centro de Ciências Naturais e Exatas, Universidade Federal de Santa Maria, 97105-900 Santa Maria-RS, Brasil. pricanesqui@yahoo.com.br

${ }^{2}$ Departamento de Biologia, Centro de Ciências Biológicas e da Saúde, Universidade Federal de Mato Grosso do Sul, Caixa Postal 549, $79080-900$ Campo Grande-MS, Brasil.ggraciolli@yahoo.com.br
\end{abstract}

\begin{abstract}
Insects associated with syconia of Ficus citrifolia in central Brazil. Fig trees present a diverse interaction with different groups of organisms. The inflorescence, or syconium, has characteristics that form a microenvironment in which interactions occur between fig trees and invertebrates. This study aimed to identify the insect fauna associated with the figs of Ficus citrifolia and to quantitatively describe the distribution pattern of the insects in the syconium, in an urban area in central Brazil. The syconia were used by 12 species of insects. Our results showed that the insects found on Ficus citrifolia presented a pattern of occurrence that depends on the composition of species found within each syconium.
\end{abstract}

KEYWORDS. Agaonidae; fig wasp; micro-hymenopteran; plant-insect interaction; pollination.

RESUMO. Insetos associados aos sicônios de Ficus citrifolia no Brasil Central. Figueiras apresentam uma diversificada interação com diferentes grupos de organismos. Sua inflorescência, ou sicônio, possui características que formam um microambiente onde ocorrem as interações entre figueiras e invertebrados. Este trabalho teve como objetivo identificar a fauna de insetos associados à sicônios de Ficus citrifolia, além de descrever quantitativamente o padrão de distribuição dos insetos nos sicônios, em área urbana no Centro-Oeste brasileiro. Os sicônios estavam infestados por 12 espécies de insetos. Nossos resultados mostraram que insetos encontrados em Ficus citrifolia apresentaram um padrão de ocorrência que depende da composição de espécies dentro de cada sicônio.

PALVRAS-CHAVE. Agaonidae; interação inseto-planta; micro-himenópteros; polinização; vespa-de-figo.

The genus Ficus L., 1754 is composed of about 750 species worldwide, about 100 species of which occur in the Neotropics (Berg \& Villavicencio 2004). Fig trees have a complex obligate mutualistic relationship with their pollinators and diversified interactions with different groups of organisms (Compton et al. 1996; West et al. 1996; Weiblen 2002; Kjellberg et al. 2005; Harrison et al. 2008). The main characteristic of this genus is its inflorescence, or syconium, which is shaped like an urn and in which the flowers grow. The only opening to the outside (ostiole) is formed by overlaying bracts (Janzen 1979). Due to these unique features, figs present a micro-environment where interactions between fig trees and invertebrates occur, forming a microcosm, where mutualistic and antagonistic relationships are established (Jackson 2004).

Pollination of figs is performed by female wasps of the family Agaonidae (Chalcidoidea), who deposit pollen and eggs in the pistillate flowers. In the ovaries in which pollen was deposited, seed development occurs, while in the ovaries where the eggs were deposited larvae developed (Weiblen 2002). The fig syconia are also exploited by different groups of organisms that are non-pollinators, such as wasp species of the families Pteromalidae, Torymidae and Eurytomidae
(Boucek 1993; Weiblen 2002), since they deposit their eggs from the outside, and other arthropods such as beetles and butterfly larvae, mites and drosophilid flies (Lachaise et al. 1982; Bronstein 1988a; Frank \& Thomas 1996; Pereira et al. 2000; Schifler 2002; Sugiura \& Yamazaki 2004).

Most studies about the exploitation of fig syconia by different organisms are related to their influence on the reproductive success of the plant and reproductive success of their pollinators (Bronstein 1988a, b; Kerdelhué \& Rasplus 1996; Pereira et al. 2000; Pereira \& Prado 2005a, b; Elias et al. 2007). In Brazil, some authors used Ficus citrifolia P. Miller, 1768 for studies of this relationship (Pereira et al. 2000 referred to as Ficus eximia Schott, 1827; Pereira et al. 2003; Pereira \& Prado 2005a, b; Elias et al. 2007; Pereira et al. 2007a, b; Elias et al. 2008). However, quantitative studies of the relationship between fig trees and insects associated with their syconia are scarce (Farache et al. 2009). Here we identified the insect fauna associated with syconia and quantitatively described the distribution of these insects in $F$. citrifolia.

The study was conducted in an urban area in the central region of Campo Grande, state of Mato Grosso do Sul, Brazil $\left(20^{\circ} 28^{\prime} \mathrm{S}, 54^{\circ} 36^{\prime} \mathrm{W}\right)$. Thirty three syconia were collected 
Table I. Insects associated with syconia of Ficus citrifolia in Campo Grande, MS, Brazil. Numbers in parenthesis correspond to 95\% confidence interval. * insufficient number of samples to calculate the confidence interval.

\begin{tabular}{lcccc}
\hline Associated Species & $\mathrm{N}$ & Number of infested syconium & Frequency of occurance & Mean intensity \\
\hline Pegoscapus sp. & 3,617 & 33 & $100.0(89.4-100.0)$ & $109.6(98.1-121.3)$ \\
Idarnes sp. 1 (group carme) & 797 & 28 & $84.8(68.1-94.9)$ & $28.5(22.0-36.7)$ \\
Idarnes sp. 2 (group carme) & 237 & 20 & $60.6(42.1-77.1)$ & $11.9(8.6-16.6)$ \\
Idarnes sp. 3 (group carme) & 9 & 1 & $3.0(0.7-15.8)$ & $9.0^{*}$ \\
Idarnes sp. 4 (group carme) & 12 & 4 & $12.1(3.4-28.2)$ & $3.0^{*}$ \\
Idarnes sp. 5 (group carme) & 105 & 21 & $63.3(45.1-79.6)$ & $5.0(4.0-6.6)$ \\
Aepocerus sp. 1 & 23 & 7 & $21.2(9.0-38.9)$ & $3.3(2.0-4.9)$ \\
Heterandrium sp. & 7 & 3 & $9.1(1.9-24.3)$ & $1.7^{*}$ \\
Physothorax sp. 1 & 40 & 14 & $42.4(25.5-60.8)$ & $2.9(1.9-3.8)$ \\
Physothorax sp. 2 & 13 & 4 & $12.1(3.4-28.2)$ & $3.3^{*}$ \\
Lygaeidae (nymph) & 2 & 1 & $3.0(0.7-15.8)$ & $2.0^{*}$ \\
Staphylinidae & 1 & 1 & $3.0(0.7-15.8)$ & $1.0^{*}$
\end{tabular}

from one $F$. citrifolia individual (subgenus Urostigma, section Americana). This tree usually has an hemi-epiphytic habit and grows on other trees or buildings often being found in disturbed areas (Pereira et al. 2007b). Male-phase syconia were collected and placed individually in plastic vials and maintained in the laboratory for about 48 hours to collect all emerged wasps. After 48 hours we added 70\% alcohol to each vial and the syconia were dissected to search for other insects. Wasps were identified up to the genus level according to Bouček (1993), Rasplus \& Soldati (2006) and Farache \& Pereira (2010). The other groups of insects found were identified to the lowest possible taxonomic level. The specimens were deposited in the Zoological Reference Collection of the Federal University of Mato Grosso do Sul, Campo Grande, MS, Brazil.

The indices used to describe the distribution of species in the syconia were the frequency of occurrence (number of infested syconia/number of collected syconia X 100) and mean intensity (number of individuals of species $\mathrm{x} /$ number of syconia infested by the species x) (Bush et al. 1997).

We found 12 species of insects in the 33 syconia, totaling 4,863 individuals. There were 10 species of wasps (Hymenoptera, Chalcidoidea), one species of seed bug (Hemiptera, Lygaeidae) and one species of beetle (Coleoptera, Staphylinidae) (Table I). For the wasp species, Pegoscapus sp. 1 (Agaonidae, Agaoninae) was found in all analyzed syconia and is the pollinating species of $F$. citrifolia. We found four species of the genus Idarnes Walker, 1843 (Incertae sedis, Sycophaginae), one species of each of the genera Heterandrium Mayr, 1885 and Aepocerus Mayr, 1885 (Pteromalidae, Otitesellinae), and two species of the genus Physothorax Mayr, 1885 (Torymidae, Toryminae). The frequency of occurrence of species that infested the syconia varied a little more than the average intensity (Table I). The species Pegoscapus sp. 1 was the most prevalent (100\%) and with greater average intensity (109.61). The genus Idarnes showed high frequency of co-occurrence with Pegoscapus sp. 1 (Table II).

This study is the first to report the insect fauna associated with the syconia of a species of the genus Ficus in the midwestern region of Brazil. As in other sites, the fig species studied here also presented a diverse interaction with different insect species (Bronstein 1988a, b; Frank \& Thomas 1996; West et al. 1996; Pereira et al. 2000; Schiffler 2002; Sugiura \& Yamazaki 2004; Nazareno et al. 2007). In urban areas in the cities of Campinas $\left(22^{\circ} 54^{\prime} \mathrm{S}, 47^{\circ} 03^{\prime} \mathrm{W}\right)$ and Londrina $\left(23^{\circ} 18^{\prime} \mathrm{S}, 51^{\circ} 09^{\prime} \mathrm{W}\right)$ syconia of $F$. citrifolia presented 15 species of insects in five crops and 14 species in eight crops, respectively (Pereira 1998).

As in the present study, Staphylinidae beetles were also found in Florida and Costa Rica (Frank \& Thomas 1996; Bronstein 1988b) and were considered predators of fig wasps. Seed bugs in the family Lygaeidae are known to be seed predators and were also found feeding on seeds of Ficus in Africa and India (Slater 1972). However, in other studies, these insects were found outside of the syconia, different from the results found here.

Pegoscapus sp. 1 shows high frequency of occurrence and intensity in the analyzed syconia (Table I). However, this species was observed in lower infestations in urban areas of Campinas, Londrina and Ribeirão Preto (2 $1^{\circ} 10^{\prime} \mathrm{S}$; $\left.47^{\circ} 48^{\prime} \mathrm{W}\right)$, due to parasitism and/or competition with nonpollinating wasps, mostly belonging to the genus Idarnes (Elias et al. 2007). Idarnes are the most abundant inquilines and competitors in the New World (West \& Herre 1994). Some species of Idarnes (group carme) are inquilines, laying eggs into galls induced by Pegoscapus spp. (Pereira et al. 2007a; Elias et al. 2008), whereas other groups (e.g. incerta and flavicollis groups) are gallers, depositing their eggs in syconia prior to pollination (Elias et al. 2008). This

Table II. Frequency of co-occurrence of wasps in figs of Ficus citrifolia in Campo Grande, MS, Brazil.

\begin{tabular}{lc}
\hline Association & Frequency (\%) \\
\hline $\begin{array}{l}\text { Pegoscapus }+ \text { Idarnes (group carme) } \\
\text { Pegoscapus }+ \text { Idarnes (group carme) }+ \text { Idarnes } \\
\text { (group incerta) }\end{array}$ & 97.0 \\
$\begin{array}{l}\text { Pegoscapus }+ \text { Idarnes (group carme) }+ \text { Idarnes } \\
\text { (group incerta) }+ \text { Aepocerus }\end{array}$ & 63.3 \\
$\begin{array}{l}\text { Pegoscapus }+ \text { Idarnes (group carme) }+ \text { Idarnes } \\
\text { (group } \text { incerta) }+ \text { Aepocerus }+ \text { Physothorax }\end{array}$ & 15.2 \\
\hline
\end{tabular}


type of exploration may explain the high frequency of cooccurrence of Idarnes (group carme) and Pegoscapus, showing a dependency relationship between these species. The biology of Aepocerus, Heterandrium and Physothorax genera are not well known, but these species are considered inquilines or parasitoids by some authors (West et al. 1996; Pereira et al. 2000; Elias et al. 2008). This fact may explain the lower occurrence and average intensity of these species, since parasitoids are less frequent, depending on the presence of their hosts in the syconia.

The fauna of insects associated with $F$. citrifolia in Campo Grande is similar to that found in other locations in Brazil (Pereira 1998; Pereira \& Prado 2005a; Pereira et al. 2000; Farache \& Pereira 2010). The quantitative analysis of interactions between these organisms demonstrated a pattern of occurrence in each syconium that depends on the composition of species found within the syconium.

Acknowledgements. We are grateful to R. A. S. Pereira for discussions regarding the fig-fig wasp system, to F. H. A. Farache for help identifying fig wasps and to R. L. Munin for comments on the manuscripts. Financial support was provided by a CNPq productivity grant (\# 304459/2008-9) to G. Graciolli and by a CAPES grant to P. C. Costa.

\section{REFERENCES}

Berg, C. C. \& X. Villavicencio. 2004. Taxonomic studies on Ficus (Moraceae) in the West Indies, extra-Amazonian Brazil and Bolivia. Ilicifolia 5: $1-132$.

Boucek, Z. 1993. The genera of chalcidoid wasp from Ficus fruit in the New World. Journal of Natural History 27: 173-217.

Bronstein, J. L. 1988a. Mutualism, Antagonism and the Fig-Pollinator Interaction. Ecology 69: 1298-1302.

Bronstein, J. L. 1988b. Predators of Fig Wasps. Biotropica 20: 215-219.

Bush, A. O.; K. D. Lafferty; J. M. Lotz \& A. W. Shostak. 1997. Parasitology meets ecology on it own terms: Margolis et al. revisited. Journal of Parasitology 83: 575-583.

Compton, S. G.; J. T. Wiebes \& C. C. Berg. 1996. The biology of fig trees and their associated animals. Journal of Biogeography 23: 405-407.

Elias, L. G.; V. T. Ó; F. H. Farache \& R. A. S. Pereira. 2007. Efeito de vespas não-polinizadoras sobre o mutualismo Ficus - vespas de figos. Iheringia (Série Zoologia) 97: 253-256.

Elias, L. G.; A. O. Menezes Jr. \& R. A. S. Pereira. 2008. Colonization sequence of non-pollinating fig wasps associated with Ficus citrifolia no Brazil. Symbiosis 45: 107-111.

Farache, F. H. A.; V. T. do Ó \& R. A. S. Pereira. 2009. New occurence of nonpollinating fig wasps (Hymenoptera: Chaldidoidea) in Ficus microcarpa in Brazil. Neotropical Entomology 38: 683-685.

Farache, F. H. A. \& R. A. S. Pereira. 2010. Comunidade de vespas (Hymenoptera, Chalcidoidea) associadas a algumas espécies Neotropicais de Ficus (Moraceae). Dissertação de mestrado. Faculdade de Ciências e Letras de Ribeirão Preto, Universidade de São Paulo.

Frank, J. H. \& M. C. Thomas. 1996. A new species of Charoxus (Coleoptera: Staphylinidae) from native figs (Ficus spp.) in Florida. Journal of the New York Entomological Society 104: 70-78.

Harrison, R. D.; N. Ronsted \& Y.-Q. Peng. 2008. Fig and fig wasp biology: a perspective from the East. Symbiosis 45: 1-8.

Jackson, A. P. 2004. Cophylogeny of the Ficus microcosm. Biological Review 79: 751-768.

Janzen, D. H. 1979. How to be a fig. Annual Review of Ecology and Systematics 10: $13-51$.

Kerdelhué, C. \& J.-Y. Rasplus. 1996. Non-pollinating Afrotropical fig wasps affect the fig-pollinator mutualism in Ficus within the subgenus Sycomorus. Oikos 75: 3-14.

Kjellberg, F.; E. Jousselin; M. Hossaert-McKey; J.-Y. Rasplus. 2005. Biology, Ecology and Evolution of Fig-pollinating Wasps (Chalcidoidea, Agaonidae). p. 539-571. In: Raman, A.; Schaefer, C. W. \& Withers, T. M. (eds.). Biology, ecology and evolution of gall-inducing arthropods. New Hampshire, Science, 817 p.

Lachaise, D.; L. Tsacas \& G. Couturier. 1982. The Drosophilidae Associated with Tropical African Figs. Evolution 36: 141-151.

Nazareno, A. G.; R. B. Q. Silva \& R. A. S. Pereira. 2007. Fauna de Hymenoptera em Ficus spp. (Moraceae) na Amazônia Central, Brasil. Iheringia (Série Zoologia) 97: 441-446.

Pereira, R. A. S. 1998. Relação do desenvolvimento de vespas de figo (Hymenoptera: Chalcidoidea) com aspectos reprodutivos de Ficus eximia Schott (Moraceae). Dissertação de mestrado. Campinas, Universidade Estadual de Campinas, $70 \mathrm{p}$.

Pereira, R. A. S.; J. Semir \& A. O. Menezes Jr. 2000. Pollination and other interactions in figs of Ficus eximia Schott (Moraceae). Revista Brasileira de Botânica 23: 217-224.

Pereira, R. A. S.; A. P. Prado \& F. Kjellberg. 2003. Gynandromorphism in pollinating fig wasps (Hymenoptera: Agaonidae). Entomological News 114: $152-155$.

Pereira, R. A. S. \& A. P. Prado. 2005 a. Non-pollinating wasps distort the sex ratio of pollinating fig wasps. Oikos 110: 1-7.

Pereira, R. A. S. \& A. P. Prado. 2005 b. Recognition of competitive asymmetries reduces the severity of fighting in male Idarnes fig wasps. Animal Behavior 70: 249-256.

Pereira, R. A. S.; S. P. Teixeira \& F. Kjellberg. 2007 a. An inquiline fig wasp using seeds as a resource for small male production: a potencial first step for the evolution of new feeding habitats. Biological Journal of the Linnean Society 92: 9-17.

Pereira, R. A. S.; E. Rodrigues \& A. O. Menezes Jr. 2007 b. Phenological patterns of Ficus citrifolia in a seasonal humid-subtropical region in Southern Brazil. Plant Ecology 188: 265-275.

Rasplus, J. Y. \& L. Soldati. 2006. Familia Agaonidae. p. 683-698. In: Fernández, F. \& Sharkey, M. J. (eds.). Introducción a los Hymenoptera de la Región Neotropical. Bogotá, Sociedad Colombiana de Entomología \& Universidad Nacional de Colombia, 896 p.

Schiffler, G. 2002. Fig wasps (Hymenoptera: Agaonidae) associated to Ficus mexiae Standl (Moraceae) in Lavras, Minas Gerais, Brazil. Neotropical Entomology 31: 653-655.

Slater, J. A. 1972. Lygaeid bugs (Hemiptera: Lygaeidae) as seed predators of figs. Biotropica 4: 145-151.

Sugiura, S. \& K. Yamazaki. 2004. Moths boring into Ficus syconia on Iriomote Island, south-western Japan. Entomological Science 7: 113118.

Weiblen, G. D. 2002. How to be a fig wasp. Annual Review of Enotmology 47: 299-330.

West, S. A. \& E. A. Herre. 1994. The ecology of the New World figparasitizing wasps Idarnes and implications for the evolution of the fig-pollinator mutualism. Proceedings of the Royal Society of London, séries B, Biological Sciencies 258: 67-72.

West, S. A.; E. A. Herre; D. M. Windsor \& P. R. S. Green. 1996. The ecology and evolution of the New World non-pollinating fig wasp communities. Journal of Biogeography 23: 447-458. 